\title{
Upaya Dosen Tahsin Al-Qiraah dalam Meningkatkan Kemampuan Membaca Al-Quran Mahasiswa Jurusan Syari'ah Institut Agama Islam Negeri Curup
}

\author{
Busra Febriyarni \\ Institut Agama Islam Negeri (IAIN) Curup, Indonesia \\ bundabusra@gmail.com
}

\begin{abstract}
This paper is intended to examine and describe tahsin al-qiraah activities, constraints and efforts of lecturers to succeed the activity. For this reason, teaching staff must strive to create students who are qualified in the field of Islam. In this case it must start from the basic course of reading Al-Quran or tahsin al-qiraah. what efforts were made by the Al-Qiraah doctoral lecturer to improve the Qoran reading ability of Sharia majors. This type of research was field research, with a qualitative descriptive approach. The results of this study indicate that the ability to read the Qoran to Syari'ah IAIN Curup students relatively was still classified as medium, with a count of $50 \%$ had been able to read well, and 50\% again needed intensive and programmed guidance. The causes of factors were less able to read the Qoran for Curup IAIN Syari'ah students, including previous student educational background, process selection of students at the time of admission of new students who do not pay attention to the standard of reading the Qoran for prospective students of IAIN Curup, Family factors that pay less attention to read Al-Quran seriously lazy to learn to read the Qoran. Efforts to improve and improve students' ability to read al-Quran include IAIN policies, uniform material, lecturer, curriculum, media, and other facilities such as rooms and learning resources.
\end{abstract}

Keywords: Effort; Lecturer; Tahsin al-Qiraah

\begin{abstract}
Abstrak
Tulisan ini dimaksudkan untuk meneliti dan mendeskripsikan kegiatan tahsin al-qiraah, kendala dan upaya dosen untuk mensukseskan kegiatan tersebut. Tujuan yang ditetapkan adalah untuk mendeskripsikan kegiatan, kendala dan upaya yang telah dilakukan dosen tahsin qiraah sehingga akan ditemukan sebuah penilaian dalam rangka peningkatan mutu IAIN Curup ke depan. Jenis penelitian ini adalah penelitian lapangan, dengan pendekatan deskriptif kualitatif. Hasil dari penelitian ini menunjukkan bahwa kemampuan membaca al-Quran pada mahasiswa Syari'ah IAIN Curup masih tergolong sedang, dengan hitungan 50\% sudah bisa membaca dengan baik, dan 50\% lagi perlu bimbingan yang intensif dan terprogram. Faktor penyebab kurang mampu membaca alQuran bagi mahasiswa Syari'ah IAIN Curup antara lain latar belakang pendidikan mahasiswa sebelumnya, proses seleksi mahasiswa pada saat penerimaan mahasiswa baru yang kurang memperhatikan standar membaca al-Quran bagi calon mahasiswa IAIN Curup, Faktor keluarga yang kurang memperhatikan baca Al-Quran anaknya
\end{abstract}

FOKUS : Jurnal Kajian Keislaman dan Kemasyarakatan Vol. 3, No. 2, 2018

P3M Sekolah Tinggi Agama Islam Negeri (STAIN) Curup - Bengkulu

Available online: http://journal.staincurup.ac.id/index.php/JF

p-ISSN 2548-334X, e-ISSN 2548-3358 
secara serius serta internal mahasiswa itu sendiri yang jarang mengaji dan malas belajar membaca Al-Quran.

Kata Kunci: Upaya; Dosen; Tahsin al-Qiraah

\section{PENDAHULUAN}

Institut Agama Islam Negeri Curup (Selanjutnya disebut IAIN Curup) adalah salah Perguruan Tinggi Agama Islam yang mayoritas mata kuliahnya didasarkan pada pengembangan Al-Quran dan Sunnah. Oleh karenanya para dosen dan mahasiswa harus bisa membaca Al-Quran dengan baik dan benar.

Selama ini yang menjadi perbincangan dan permasalahan yang dihadapi di IAIN Curup adalah masih banyaknya mahasiswa yang belum mampu membaca Al-Quran dengan benar (dilihat dari makhraj, tajwidnya). Berdasarkan pantauan peneliti di antara penyebabnya adalah sebelum masuk IAIN masih banyak yang belum bisa membaca Al-Quran atau mengaji, kemudian setelah masuk kuliah diberikan mata kuliah tahsin al-qiraah, inipun masih ada sebagian yang belum lancar membacanya. Hal ini mengakibatkan banyak mata kuliah yang berhubungan dengan membaca Al-Quran dan bahasa Arab sulit untuk diikuti, seperti mata kuliah tafsir, hadis, bahasa Arab, fikih, membaca kitab, materi Quran Hadis.

Seluruh Program Studi di IAIN Curup harus mengambil mata kuliah di atas. Bagi yang kurang mampu membaca Al-Quran dengan baik akan menghadapi kendala ketika menerima mata kuliah ini. Bahkan yang lebih mengkhawatirkan adalah ketika mereka akan ujian praktek mengajar dan Kuliah Pengabdian Masyarakat (KPM), juga sangat dituntut bacaan AlQuran yang baik dan benar. Sebuah kemustahilan seorang calon guru Agama Islam tidak mampu membaca Al-Quran dengan baik dan benar.

Hal inilah yang menggugah peneliti ingin memunculkan sebuah kajian dalam bentuk penelitian untuk menemukan upaya solutif dalam rangka meningkatkan kemampuan membaca Al-Quran mahasiswa IAIN Curup. Persoalan ini senantiasa menjadi problem berkepanjangan beberapa tahun terakhir ini, semenjak jumlah mahasiswa IAIN Curup naik secara signifikan. Harapan civitas akademika adalah peningkatan mutu Tenaga pengajar dan mahasiswa dari seluruh aspek, terutama membaca Al-Quran. 
Mahasiswa sangat dituntut untuk dapat membaca Al-Quran dengan baik dan benar, karena ini adalah identitas seorang mahasiswa Perguruan Tinggi Islam. Akan menjadi suatu hal yang lucu dan memalukan, jika ada mahasiswa Perguruan Tinggi yang berlabel Islam tidak mampu membaca Al-Quran dengan baik dan benar. Oleh sebab itu, ketika penerimaan mahasiswa baru yang menjadi syarat utama adalah seleksi membaca AlQuran. Kemudian jika dinyatakan lulus sebagai mahasiswa IAIN Curup, maka salah satu usaha yang dilakukan adalah mengembangkan kemampuan membaca Al-Quran tersebut dengan memberikan mata kuliah tahsin al-qiraah. Mata kuliah ini sesungguhnya bukan mengajarkan baca Alquran dari nol, tetapi hanya memperbaiki atau memperindah bacaannya. Mata kuliah ini adalah nol sks, tetapi sebagai syarat mutlak untuk mengikuti ujian akhir yaitu ujian komprehensif dan munaqasyah. ${ }^{1}$

Dalam rangka peningkatan mutu IAIN Curup ke depan, sesungguhnya harus diawali dengan peningkatan baca Al-Quran dan pengamalannya dalam berbagai disiplin ilmu dan kehidupan. Untuk itu sebagai tenaga pengajar harus berupaya menciptakan anak didik yang qualified di bidang agama Islam. Dalam hal ini harus dimulai dari mata kuliah dasar yaitu membaca Al-Quran atau tahsin al-qiraah. Mata kuliah tahsin al-qiraah adalah mata kuliah prasyarat yang diberikan di semester satu atau dua.

Problem yang ditemukan di lapangan adalah masih banyaknya mahasiswa IAIN curup yang belum lancar membaca Al-Quran dengan baik dan benar. Ini dibuktikan dengan adanya sebahagian mereka yang sudah semester 7 dan 8 ketika mengikuti ujian komprehensif dan ujian munaqasyah belum lancar membaca Al-Quran. Sementara mereka sudah harus tamat dan akan mengajar serta mempraktekkan ilmunya di tengah masyarakat. Hal inilah yang menggelitik peneliti sebagai dosen tafsir hadis di IAIN Curup ingin mengkaji hal ini. Penelitian ini akan terfokus pada upaya dosen tahsin al-qiraah dalam meningkatkan kemampuan membaca Al-Quran mahasiswa IAIN Curup. Dengan tujuan bisa memberikan solusi dari persoalan ini, dengan melihat akar penyebab kurang mampunya mahasiswa membaca Al-Quran, upaya para dosen untuk meningkatkan kemampuan mereka serta hambatan-hambatan yang

\footnotetext{
${ }^{1}$ Pedoman Akademik dan Kode Etik Mahasiswa, (Curup: LP2 IAIN Curup, 2010), h.69.
} 
menyebabkan hal tersebut terjadi. Penelitian ini akan peneliti kaji dan analisa secara mendalam dengan judul, "Upaya Dosen Tahsin al-Qiraah untuk Meningkatkan Kemampuan Membaca Al-Quran Mahasiswa jurusan Syariah IAIN Curup".

Permasalahan penting yang dihadapi IAIN Curup beberapa tahun terakhir ini sampai sekarang adalah, kemampuan membaca Al-Quran mahasiswa yang masih kurang. Ini dibuktikan dengan masih banyak dari mahasiswa yang belum fasih membaca Al-Quran. Sementara salah satu syarat Perguruan Tinggi Islam yang bermutu adalah memiliki lulusan yang berkualitas. Lulusan yang berkualitas pertama kali akan dilihat dari kemampuan para alumninya membaca Al-Quran dengan baik dan benar. Masih banyak dari mahasiswa yang akan tamat belum lancar membaca Al-Quran. Ini adalah persoalan yang sangat serius untuk dicarikan solusinya. Beberapa masalah yang bisa peneliti inventaris adalah sebagai berikut : 1) banyaknya calon mahasiswa IAIN Curup yang tidak bisa membaca Al-Quran; 2) setelah lulus seleksi masih banyak di antara mahasiswa yang belum tuntas mengaji Iqra'; 3) praktikum tahsin alqiraah adalah salah satu upaya yang dilakukan IAIN Curup untuk memperbaiki, memperindah bacaan mahasiswa; 4) proses pembelajaran tahsin al-qiraah selama satu semester tidak mencukupi standar kemahiran membaca Al-Quran mahasiswa; 5) jika pada kuliah tahsin al-qiraah, mahasiswa masih belum bisa dan lancar membaca Al-Quran, mahasiswa belum bisa melanjutkan mata kuliah prasyarat lainnya seperti pratikum ibadah 1 dan 2; 6) sudah banyak dari UKM mahasiswa yang mengadakan privat tambahan untuk belajar membaca Al-Quran; 7) diperoleh kendala yang signifikan ketika mengikuti mata kuliah yang berhubungan dengan kemampuan membaca Al-Quran seperti mata kuliah bahasa Arab, tafsir, hadis, fiqh, membaca kitab, ushul fiqh serta metode pemahaman Quran Hadis, mereka susah mengikutinya; 8) banyaknya mahasiswa yang belum lulus ujian komprehensif mata kuliah Quran Hadis praktis, bahasa Arab, dan membaca kitab, karena kurang mampu membaca Alquran; 9) banyaknya mahasiswa yang ingin mengikuti ujian munaqasyah belum lancar membaca Al-Quran ${ }^{2}$; 10) setelah menjadi alumni pun, masih ada juga di antara mereka yang belum fasih membaca Al-Quran.

\footnotetext{
${ }^{2}$ Salah satu solusi sudah ditawarkan di prodi Perbankan Syariah pada tahun ini (2014), bagi mahasiswa yang akan mengikuti ujian komprehensif harus dibuktikan dengan surat keterangan sudah lancar membaca Al-Quran yang diuji oleh dosen Penasehat Akademik
} 
Inilah beberapa identifikasi masalah yang bisa peneliti paparkan dalam rancangan proposal ini. Sesungguhnya masih banyak kendala lain yang dihadapi mahasiswa yang berhubungan dengan membaca Al-Quran. Oleh karena itu, penulis sangat tertarik untuk mengkaji problem ini, dengan harapan bisa memberikan secercah perbaikan untuk peningkatan mutu IAIN Curup ke depan.

Berdasarkan beberapa identifikasi masalah di atas maka tujuan penelitian ini adalah untuk mengetahui : 1) bagaimana kemampuan membaca Al-Quran mahasiswa jurusan Syari'ah IAIN Curup; 2) apakah faktor penyebab kurang mampunya mahasiswa Syari'ah IAIN Curup membaca Al-Quran; 3) bagaimana upaya para dosen tahsin al-qiraah untuk meningkatkan kemampuan membaca Al-Quran mahasiswa Syari'ah IAIN Curup.

Agar penelitian ini dapat terfokus dan tidak melebar, maka peneliti akan memberikan batasan kajian seputar upaya apa saja yang dilakukan dosen tahsin al-qiraah untuk meningkatkan kemampuan membaca AlQuran mahasiswa. Upaya tersebut adalah dari segi teknik dan metode pengajaran, materi yang cepat dan mudah dipahami mahasiswa agar cepat mahir membaca Al-Quran, media apa yang cocok diberikan untuk kelangsungan pembelajaran yang mudah, cepat dan tepat.

Jenis penelitian ini adalah penelitian lapangan, dengan pendekatan deskriptif kualitatif. ${ }^{3}$ Pendekatan deskriptif adalah metode yang berusaha menggambarkan dan menginterpretasikan objek sesuai apa adanya. ${ }^{4}$ Pendekatan deskriptif kualitatif yang dimaksud di sini adalah penggambaran objek di lapangan sesuai dengan yang sesungguhnya terjadi di tempat penelitian, yaitu di IAIN Curup.

masing-masing. Jika sudah lancar membaca Alquran, maka mereka layak menerima surat keterangan dari PA dan Ka,Prodi.

${ }^{3}$ Burhan Bungin ed. Metodologi Penelitian Kualitatif, Aktualisasi Metodologiske Arah Ragam Varian Kontemporer, (Jakarta: PT. Raja Grafindo Persada, 2007), h. 41

${ }^{4}$ Sukardi, Metodologi Penelitian Pendidikan, (Jakarta: Bumi Aksara, 2003), h. 157 


\section{PEMBAHASAN \\ Kemampuan Mahasiswa Syari'ah IAIN Curup dalam Membaca Al- Quran}

Kemampuan membaca al-Quran pada mahasiswa Syari'ah IAIN Curup masih tergolong masih kurang baik, hal ini sebagaimana yang disampaikan dosen pengajar tahsin al-Qiraah. ${ }^{5}$ Begitu juga dengan jawaban dosen lain yang mengatakan kemampuan mahasiswa jurusan Syariah tergolong sedang. Jika dikelompokkan yang bisa setengah dan yang belum bisa juga setengah. ${ }^{6}$ (Bagaimana pendapat Ibu/Bapak mengenai kemampuan membaca al-Quran pada mahasiswa Syari'ah IAIN Curup?)

Tingkatan kemampuan membaca al-Quran mahasiswa Syari'ah IAIN Curup dapat dikategorikan pada tingkat sangat mendasar. Artinya mahasiswa belum dapat membaca dengan baik, dari segi makhraj alhuruf maupun aturan atau hukum bacaannya. (Menurut Ibu/Bapak tingkatan (kalau dapat dikategorikan) kemampuan membaca al-Quran Mahasiswa Syari'ah IAIN Curup pada tingkat bagaimana?)

Dari 100\% jumlah mahasiswa Syari'ah IAIN Curup, yang masih perlu mendapatkan bimbingan dan pengembangan sekitar $50 \%$ dari jumlah total. Artinya dari 200 mahasiswa mahasiswa Syari'ah IAIN Curup, sekitar 100 mahasiswa yang masih perlu bimbingan membaca alQuran secara intensif. (Dari 100\% jumlah Mahasiswa Syari'ah IAIN Curup, menurut Ibu/Bapak berapa persenkah yang masih perlu bimbingan dan pengembangan?)

Kemampuan membaca al-Quran yang rendah sangat mempengaruhi mahasiswa dalam proses perkuliahan, terutama pada mata kuliah yang memerlukan kemampuan membaca al-Quran dengan baik seperti mata kuliah Bahasa Arab, Ilmu Hadis, Tafsir Al-Quran. Pengaruhnya tidak hanya terhadap mahasiswa yang bersangkutan akan tetapi juga kepada mahasiswa yang lain. Artinya jika dalam satu lokal terdapat 30 mahasiswa maka 15 mahasiswa yang tergolong mampu membaca alQuran dengan baik akan mengikuti materi yang diberikan kepada

\footnotetext{
${ }^{5}$ Wawancara dengan dosen Tahsin al-Qiraah prodi PS dengan inisial YS pada tanggal 22 agustus 2014

${ }^{6}$ Wawancara dengan dosen tahsin Al-qiraah prodi PS dengan inisial NP pada tanggal 7 Oktober 2014
} 
mahasiswa dengan kemampuan membaca al-Quran kurang baik sehingga pencapaian materi bagi mereka mahasiswa yang sudah baik mendapatkan materi yang kurang maksimal. (Menurut Ibu/Bapak kemampuan membaca al-Quran yang rendah sangat mengganggu proses perkuliahan untuk mata kuliah yang memerlukan kemampuan membaca al-Quran, tidak hanya untuk dirinya sendiri akan tetapi juga berpengaruh pada proses perkuliahan secara keseluruhan, mengapa?

\section{Faktor yang Menyebabkan Kurang Mampu Membaca Al-Quran pada Mahasiswa Syari'ah IAIN Curup}

Faktor penyebab kurang mampu membaca al-Quran bagi mahasiswa Syari'ah IAIN Curup antara lain latar belakang pendidikan mahasiswa sebelumnya dan lingkungan keluarga yang kurang mendukung belajar membaca al-Quran. Faktor lain yang menyebabkannya adalah proses seleksi mahasiswa pada saat penerimaan mahasiswa baru yang kurang memperhatikan standar membaca al-Quran bagi calon mahasiswa IAIN Curup, faktor keluarga yang kurang memperhatikan baca Al-Quran anaknya secara serius, dan yang tak kalah pentingnya adalah faktor dari internal mahsiswa itu sendiri yang jarang mengaji dan malas belajar membaca Al-Quran. ${ }^{7}$ (Menurut Ibu/Bapak apa saja penyebab kurang mampu membaca al-Quran bagi Mahasiswa Syari'ah IAIN Curup?)

\section{Upaya Para Dosen Tahsin Al-Qiraah Untuk Meningkatkan Kemampuan Membaca Al-Quran Mahasiswa Syari'ah IAIN Curup}

Upaya untuk memperbaiki dan meningkatkan kemampuan membaca al-Quran mahasiswa adalah meliputi kebijakan IAIN, materi yang seragam, SDM Dosen, kurikulum, media, serta fasilitas lain seperti ruangan dan sumber belajar. Diadakan pembelajaran intensif bagi mahasiswa yang belum bisa sama sekali, satu dosen maksimal mengampu 20 mahasiswa, kemudian kesadaran dari mahasiswa itu sendiri tentang pentingnya membaca Al-Quran. ${ }^{8}$ Selanjutnya harus diadakan pelatihan yang terprogram dan terencana setiap tahun dengan manajemen

\footnotetext{
${ }^{7}$ Wawancara dengan dosen tahsin Al-Qiraah prodi PS dengan inisial NJ pada tanggal 20 Agustus 2014

${ }^{8}$ Ibid., YS, NP, dan NJ
} 
pembelajaran yang terkontrol. ${ }^{9}$ (Selaku Dosen pada peningkatan kemampuan membaca al-Quran bagi Mahasiswa Syari'ah IAIN Curup, apa saja yang diperlukan sehingga mereka mampu memperbaiki kemampuan membaca al-Quran?)

Kebijakan IAIN sejauh ini masih perlu ditinjau dalam merencanakan perbaikan membaca al-Quran bagi mahasiswanya terlebih setelah mengetahui bahwa mahasiswa yang tersaring melalui proses penerimaan mahasiswa belum memiliki kemampuan yang baik di dalam membaca alQuran. Kebijakan yang dimaksud adalah adanya peraturan khusus yang mengatur proses perbaikan membaca al-Quran yang melibatkan segala faktor pendukung pelaksanaan perbaikan membaca al-Quran bagi mahasiswa. Namun sejauh pantauan para dosen tahsin Al-Qiraah belum adanya keseriusan dari pimpinan IAIN, hal ini terbukti dengan belum adanya IAIN mengadakan seminar khusus dosen tahsin al-Qiraah. Padahal membaca Al-Quran untuk mahasiswa IAIN adalah suatu hal yang paling pokok di atas mata kuliah yang lain. ${ }^{10}$ Adanya program khusus yang lebih intensif yang diperuntukkan bagi mahasiswamahasiswa tertentu dengan tingkatan-tingkatan tertentu. Adanya pengakuan hasil proses perbaikan membaca al-Quran untuk prasyarat mengikuti mata kuliah tertentu. (Mengenai Kebijakan IAIN, bagaimana pendapat Ibu/Bapak agar pelaksanaan dan pembinaan kemampuan membaca al-Quran dapat terlaksana dengan lebih baik? Apakah selama ini sudah baik atau belum baik?)

SDM dosen yang mengampu pembinaan baca al-Quran dalam mata kuliah tahsin al-Qira'ah sudah memiliki kapasitas yang baik dan sudah mumpuni, apalagi semuanya berlatar pondok pesantren, hanya saja yang diperlukan lebih jauh adalah penyatuan standar kompetensi dan adanya komitmen dari pimpinan untuk keseriusan persoalan ini. Jika sudah ada komitmen tersebut, maka koordinasi dengan dosen pengajar harus intensif agar dapat dilaksanakan secara baik, terarah dan terstruktur. ${ }^{11}$ Hal ini dapat dilakukan dengan dukungan kebijakan IAIN Curup yang mengatur peran dosen secara lebih rinci dan terarah. (Mengenai SDM Dosen,

\footnotetext{
${ }^{9}$ Wawancara dengan dosen tahsin Al-Qiraah prodi PA dengan inisial BR pada tanggal 7 oktober 2014

${ }^{10}$ Wawancara dengan dosen Tahsin Al-Qiraah prodi PA dengan inisial BR tanggal 6 Oktober 2014, dan Ibid., YS, NJ,NP.

${ }^{11}$ Ibid.,
} 
bagaimana pendapat Ibu/Bapak kemampuan SDM Dosen yang dilibatkan dalam pembinaan baca al-Quran (dalam mata kuliah tahsin al-Qiraah ?)

Kurikulum yang diterapkan di IAIN Curup dalam rangkan pembinaan baca al-Qur'an tergantung kepada dosen masing-masing. Dengan demikian belum ada koordinasi yang terarah dari pihak IAIN Curup. Hal ini merupakan kelemahan dalam proses pencapaian baca alQuran sehingga ukuran hasil yang didapatkan sangat bervariasi. Perlu diadakannya penetapan kurikulum yang baku yang berlaku untuk setiap dosen dan ditetapkan oleh pimpinan IAIN Curup atau pihak yang berwenang. (Mengenai Kurikulum, bagaimana pendapat Ibu/Bapak tentang hal ini?)

Media yang dapat digunakan oleh dosen pengampu mata kuliah tahsin al-Qiraah sudah cukup baik, karena media yang merupakan inventarisasi IAIN Curup pada prinsipnya dapat digunakan dalam proses perkuliahan. Seperti laboratorium bahasa untuk media audio visual. Hanya saja karena target hendak dicapai dalam proses pembinaan baca alQuran belum ada ukuran yang jelas, sehingga pada pelaksanaannya diserahkan kepada dosen masing-masing termasuk dalam hal menyediakan media yang hendak digunakan. (Mengenai Media, bagaimana pendapat Ibu/Bapak tentang hal ini?)

Fasilitas lain seperti ruangan dan sumber belajar sama halnya dengan media. Oleh karena itu perlu adanya koordinasi lebih baik mengenai penggunaannya. Sesungguhnya sudah sangat memadai. (Mengenai fasilitas lain seperti ruangan dan sumber belajar, bagaimana pendapat Ibu/Bapak tentang hal ini?)

Hal lain yang harus dilakukan dalam hal perbaikan proses pembinaan baca al-Quran adalah adanya pelatihan bagi dosen tertentu untuk menyamakan visi dan misi kegiatan perkuliahan sehingga arah yang hendak dicapai dapat dilakukan secara lebih baik. Kemudian perlu penambahan media audio visual untuk praktikum dan variasi mengajar. (Mungkin ada hal lain selain tersebut di atas, bagaimana pendapat Ibu/Bapak?)

Untuk memperkuat data dari penelitian ini, penulis juga memberikan wawancara kepada perwakilan mahsiswa jurusan Syariah yang belajar Tahsin al-Qiraah. Hal yang ditanyakan adalah 1) kemampuan Mahasiswa Syariah IAIN Curup dalam membaca Al-Quran; 2) menurut jawaban dari 
pertanyaan yang diajukan mereka mengatakan bahwa, mereka mampu membaca Al-Quran, tapi panjang pendeknya belum faham, jika ingin belajar dengan rajin dan tekun kami bisa membaca Al-Quran, kata mereka. Selanjutnya mereka juga ditanyakan tentang dari mana belajar membaca Al-Quran sebelum masuk IAIN? Mereka mengungkapkan bahwa di kampung belajar mengaji dengan orang tua dan guru mengaji, baik di rumah, di sekolah dan di Mesjid.

Kemudian mereka juga mengatakan bahwa ketika tes baca Al-Quran masuk IAIN banyak di antara mereka yang belum bisa mengaji, ditambah lagi dengan di saat mengikuti kuliah tahsin al-Qiraah semakin kelihatan dari mahasiswa yang belum bisa lancar mengaji. Jika dipresentasikan sekitar 30 sampai 40 persen yang belum lancar membaca Al-Quran. ${ }^{12}$.

Kemampuan membaca Al-Quran yang rendah menurut mereka akan mengganggu proses pembelajaran pada mata kuliah lain yang banyak kaitannya dengan baca Al-Quran. Mereka akan susah mengikuti mata kuliah lain yang notabene bermuatan agama yang seharusnya landasan yang kuat adalah mahir dan lancar membaca Al-Quran.

1. Faktor yang Menyebabkan Kurang Mampunya Mahasiswa Jurusan Syariah IAIN Curup Membaca Al-Quran.

Mereka menjawab bahwa faktor yang menyebabkan mereka kurang mampu membaca Al-Quran adalah diri sendiri yang kurang mau belajar dan juga kurang dukungan orang tua. Ada juga yang mengatakan orang tua sudah mendatangkan guru mengaji, tapi anaknya sendiri yang malas belajar dan tidak mau memahami orang tuanya. ${ }^{13}$ Hal ini menunjukkan bahwa individu atau mahasiswa itu sendiri yang kurang mau belajar mengaji atau malas lebih dominan.

2. Upaya Para Dosen Tahsin Al-Qiraah untuk Meningkatkan Kemampuan Membaca Al-Quran Mahasiswa Syariah IAIN Curup.

Mengikuti Tahsin al-Qiraah adalah wajib bagi mahasiswa semester 1 jurusan Syariah. Mata kuliah ini juga sebagai prasyarat untuk mata kuliah lainnya seperti pratikum ibadah 1, 2, tafsir, hadis, KPM, Kompre, dan ujian Skripsi.

Ketika ditanya mereka juga senang belajar tahsin untuk menambah kemahiran mereka baca Al-Quran. Hanya saja mereka perlu

\footnotetext{
${ }^{12}$ Wawancara dengan mahasiswa prodi PS yang mengambil mata kuliah tahsin al-Qiraah dengan inisial RAY dan L tanggal 7 oktober 2014

${ }^{13}$ Ibid.,
} 
bimbingan yang intensif dan serius sehingga betul-betul ada perubahan yang signifikan ketika masuk dengan setelah mengikuti proses kuliah tahsin tersebut.

Mereka juga mengatakan dosen tahsin al-Qiraah juga mengajar dengan baik dan sistimatis, tetapi sekali lagi harus dengan keseriusan antara mahasiswa dan dosen. Dengan belajar mengaji mampu meningkatkan kemampuan baca Al-Quran mereka dari belum bisa menjadi agak bisa walaupun masih harus banyak belajar. ${ }^{14}$

Setelah peneliti mencermati dari berbagai tanggapan yang telah disampaikan oleh dosen tahsin al-Qiraah, maka dapat diberikan penjelasan bahwa kemampuan membaca Al-Quran mahasiswa Jurusan Syariah masih tergolong sedang, atau dalam kategori 50\% yang sudah lancar membaca dan $50 \%$ yang belum lancar. Hal ini terlihat jelas dari masing-masing dosen menjawab dengan 50\% atau setengah-setengah.

Hal ini dilatarbelakangi oleh faktor keluarga yang tidak memperhatikan pentingnya baca tulis Al-Quran untuk anak mereka, kemudian faktor pendidikan di sekolah sebelumnya yang juga tidak menjadikan baca Al-Quran sebagai standar kelulusan. Kemudian faktor pemerintah yang belum maksimal memberikan perhatian kepada baca tulis AL-Quran. Hal lain yang tak kalah pentingnya adalah kesadaran individu itu sendiri yang sangat kurang dalam belajar membaca Al-Quran.

Persoalan ini akan bisa diminimalisir dengan baik jika semua lembaga terkait dapat bekerja sama dan berkomitmen untuk meningkatkan baca tulis Al-Quran. Pimpinan IAIN, pada dosen tahsin alQiraah dan mahasiswa sama-sama berusaha untuk perbaikan ke depan. Pimpinan menyiapkan sarana dan prasarana serta fasilitas yang lain dengan tegas mengadakan pelatihan untuk kesamaan materi, standar dan kreatifitas, dosen berupaya meningkatkan kemampuan mereka dalam mengajar, baik dari segi materi, strategi dan kompetensi mereka untuk benar-benar ikhlas mengajar, dan mahasiswa betul-betul punya kesadaran yang tinggi untuk bisa belajar Al-Quran dan dengan rutin mengulangnya di rumah untuk meningkatkan kefasihan. Jika ketiga elemen ini sudah bekerja sama dengan baik, maka akan ada perbaikan bacaan Al-Quran mahasiswa IAIN Curup ke depan, khususnya jurusan Syariah.

\footnotetext{
${ }^{14}$ Ibid.,
} 
Kemudian bagi mahasiswa yang belum bisa mengaji sama sekali perlu adanya matrikulasi khusus atau intensif belajar membaca Al-Quran, agar mereka digenjot untuk segera bisa. Difasilitasi dan diwajibkan untuk mereka yang belum bisa, jangan mengambil mata kuliah lain sebelum lancar membaca Al-Quran. Dengan demikian IAIN Curup akan memiliki mahasiswa yang berkualitas, karena mayoritas mata kuliah lain sangat terkait dengan kelancaran membaca Al-Quran.

Kurikulum yang diberikan harus diperbaharui dan direvisi, sehingga bisa memberikan pengajaran yang singkat, padat serta mudah difahami. Untuk itu kepada pihak pimpinan dan dosen yang mengajar perlu dibuat semacam pelatihan, workshop atau sejenis lokakarya agar kompetensi mereka dapat ditingkatkan.

Untuk sarana dan prasarana sesungguhnya sudah memadai, hanya saja ruangan audio visual yang perlu ditambahkan, sehingga variasi dalam proses belajar mengajar akan memudahkan mahasiswa dan dosen untuk segera meningkatkan kemampuan mahasiswa membaca Al-Quran.

\section{PENUTUP}

Penelitian ini berupaya untuk mengetahui upaya yang telah dilakukan dosen Tahsin Al-Qiraah untuk meningkatkan bacaan Al-Quran mahasiswa Jurusan Syariah.

Kemampuan membaca al-Quran pada mahasiswa Syari'ah IAIN Curup masih tergolong sedang, dengan hitungan 50\% sudah bisa membaca dengan baik, dan 50\% lagi perlu bimbingan yang intensif dan terprogram.

Kemampuan membaca al-Quran yang rendah sangat mempengaruhi mahasiswa dalam proses perkuliahan, terutama pada mata kuliah yang memerlukan kemampuan membaca al-Quran dengan baik seperti mata kuliah Bahasa Arab, Ilmu Hadis, Tafsir Al-Quran. Pengaruhnya tidak hanya terhadap mahasiswa yang bersangkutan akan tetapi juga kepada mahasiswa yang lain. Artinya jika dalam satu lokal terdapat 30 mahasiswa maka 15 mahasiswa yang tergolong mampu membaca alQuran dengan baik akan mengikuti materi yang diberikan kepada mahasiswa dengan kemampuan membaca al-Quran kurang baik sehingga 
pencapaian materi bagi mereka mahasiswa yang sudah baik mendapatkan materi yang kurang maksimal.

Faktor penyebab kurang mampu membaca al-Quran bagi mahasiswa Syari'ah IAIN Curup antara lain latar belakang pendidikan mahasiswa sebelumnya dan lingkungan keluarga yang kurang mendukung belajar membaca al-Quran. Faktor lain yang menyebabkannya adalah proses seleksi mahasiswa pada saat penerimaan mahasiswa baru yang kurang memperhatikan standar membaca al-Quran bagi calon mahasiswa IAIN Curup. Faktor keluarga yang kurang memperhatikan baca Al-Quran anaknya secara serius. Satu hal lagi yang tak kalah pentingnya adalah faktor dari internal mahasiswa itu sendiri yang jarang mengaji dan malas belajar membaca Al-Quran.

Upaya untuk memperbaiki dan meningkatkan kemampuan membaca al-Quran mahasiswa adalah meliputi kebijakan IAIN, materi yang seragam, SDM Dosen, kurikulum, media, serta fasilitas lain seperti ruangan dan sumber belajar. Diadakan pembelajaran intensif bagi mahasiswa yang belum bisa sama sekali, satu dosen maksimal mengampu 20 mahasiswa, kemudian kesadaran dari mahasiswa itu sendiri tentang pentingnya membaca Al-Quran. Selanjutnya harus diadakan pelatihan yang terprogram dan terencana setiap tahun dengan manajemen pembelajaran yang terkontrol.

\section{DAFTAR PUSTAKA}

Abdul Majid Khon, Pratikum Qira'at, Keanehan Bacaan Al-Quran Qira'at Ashim dari Hafash, Jakarta: Amzah, 2011.

Ahmad Syarifuddin, Mendidik Anak Membaca, Menulis dan Mencintai Al-Quran, Jakarta: Gema Insani Press, 2004.

Al-Qaththan Manna, mabahits fiy Ulum Al-Quran, Mansyurat al-'Ashr al-Hadits, Cet. ke-2, tth.

Ash-Shabuni, At-Tibyan fiy Ulum Al-Quran, tp., Alam al-Kutub, th.

Ash-Shiddieqy, Muhammad Hasbi, Sejarah dan Pengantar Ilmu alQuran dan Tafsir, Semarang: PT. Pustaka Rizki Pratama, 1997. 
As-Shalih, Subhi, Mabahits fiy Ulum Al-Quran, Beirut: Libanon, Dar alm al-Malayin, 1985.

As-Suyuthi, Al-Itqan Fiy Ulum Al-Quran, jilid I, th.

Buku Pedoman Akademik dan Kode Etik Mahasiswa (LP2 STAIN Curup, 2010.

Bunginjhy, Burhan ed. Metodologi Penelitian Kualitatif, Aktualisasi Metodologiske Arah Ragam Varian Kontemporer, Jakarta: PT. Raja Grafindo Persada, 2007.

Hamid, Abdul, dkk., Pembelajaran Bahasa Arab, Pendekatan Metode, Strategi, Materi dan Media, Malang: UIN Malang Press, 2008.

Irfan Supandi, Agar Bacaan Al-Quran Tak Sia-Sia, Solo, Tinta Medina, 2013.

Ismail Tekan, Tajwid Al-Quranul Karim, Jakarta: Amsah, 2009.

Khon, Abdul Majid, Pratikum Qiraat, Jakarta: Amzah, 2011.

Mahfudh Sulaiman, Ilmu Tajwid, Jepara: Yayasan Islam Mangun sejati, tth.

Muhajir, Noeng, Metodologi Penelitian Kualitatif, Yogyakarta: Rake Sarasin, 1992.

Muhammad Al-'Alawi al-Maliki Al-Hasani, Al-Itqanfiy 'Ulum Al-Quran, Saudi Arabia: Dar al-Syarq, jilid I., tth.

Nasir, Moh., Metodologi Penelitian, Jakarta: Ghalia, 1998.

Pedoman Akademik dan Kode Etik Mahasiswa, Curup: LP2 STAIN Curup, 2010.

Poerwadinata, WJS., Kamus Umum Bahasa Indonesia, Jakarta: Balai Pustaka, 2002.

Shihab, M.Quraish, Wawasan Al-Quran, Bandung: Mizan, 1996.

Sjafi'i, A. Mas'ud, Pelajaran Tajwid, Bandung: Putra Jaya, 2001.

Sukardi, Metodologi Penelitian Pendidikan, Jakarta: Bumi Aksara, 2003.

Yuniarweti, 0353025, “Analisis tentang tanggapan mahasiswa Prodi PAI Angkatan 2003-2004 terhadap pelayanan perpustakaan IAIN Curup", Skripsi. Program Study PAI IAIN Curup, 2007 h. 36-38. 
Wawancara dengan dosen Tahsin al-Qiraah prodi PS dengan inisial YS.

Wawancara dengan dosen tahsin Al-qiraah prodi PS dengan inisial NP.

Wawancara dengan dosen tahsin Al-Qiraah prodi PS dengan inisial NJ pada tanggal 20 Agustus 2014, YS, NP, dan NJ.

Wawancara dengan dosen tahsin Al-Qiraah prodi PA dengan inisial BR pada tanggal 7 oktober 2014.

Wawancara dengan dosen Tahsin Al-Qiraah prodi PA dengan inisial BR tanggal 6 Oktober 2014, dan Ibid., YS, NJ, NP.

Wawancara dengan mahasiswa prodi PS yang mengambil mata kuliah tahsin al-Qiraah dengan inisial RAY dan L tanggal 7 oktober 2014. 